\title{
亀居山大乗寺客殿の天明・寛政期に打ける再建と修繥過程に関する研究
} 障壁画注文及び製作年との関連性も含めて

\author{
STUDY ON REBUILDING AND REPAIR OF THE KAMEISAN DAIJYO-JI KYAKUDEN \\ IN TENMEI AND KANSEI PERIOD \\ Relation between order of pictures on partitions and year of production
}

木下知威*

\section{Tomotake KINOSHITA}

\begin{abstract}
The study covers the architecture of Daijyo-ji Kyakuden. Method of the study was by analyzing field conducting fieldwork, the antique documents of Daijyo-ji and research of the Japanese art history.The results from the anlysis showed the following 5 aspects. 1. Preparation for the Daijyo-ji kyakuden rebuiilding started from March 1794 of 1786. 2. Pictures on partitions other than between the room of wistaria, the monkey, the duck, and the peacock have been drawn for the Tenmei era. Most pictures were drawn in the Tenmei era except for the pictures in the room of wistaria the monkey, the duck, and the peacock. 3. It is thought that the old draft were produced before August 1787 when considering the year of the order and the year of production of pictures on partitions. 4.As for the room of wistaria, carp, and dog, the modification had not been done since the year of rebuilding. 5. It is thought that priest's living quarters were planes similar to the old draft, however it was remodeled from the situation of the Shingu-ji hondo after 1829 or 1830 .
\end{abstract}

Keywords : Superior, Priests' quarters, Kyakuden,Tenmei, Kansei, Okyo Maruyama 方丈，庫裏，客殿，天明，寛政，円山応挙

1 研究の目的 兵庫県美方郡香美町香住区にある高野山真言宗の 亀居山大乗寺は山陰本線の香住駅から南 $1.6 \mathrm{~km}$ 、円山川のほとりにあ る。ここは江戸中期の画家、円山応挙注1) 一門が描いた全 165 面の障 壁画注2)を収蔵しており、通称「応挙寺」として知られている。

大乗寺については、美術史・郷土史の面から江戸中期の大乗寺住 職であった密蔵上人注3)、密英上人注4) の業績を明らかにしたものや、 障壁画の保存・観賞に関する諸問題について論じるものがみられる 注5)。とくに、障壁画に関する既往研究は、主に江戸絵画史注6)、仏像 彫刻史注7)で蓄積され、詳細な検討がされている。客殿の建築につい ては、近畿地方における近世寺院の悉皆調查とそれに基づいた報告 がされているが注8)、年代について正確でない箇所がみられる。また、 平面分類に関する研究において、大乗寺客殿及び庫裏は L 字型空間 で仏壇のある発展型四間取りとされるが、実際は庫裏の突出部を失 った間取りであり、その理由が分析されていない注9)。そこで、本論 文では大乗寺客殿が建築された過程と現在の間取りに至った過程に ついて、日本美術史における障壁画の注文・製作年の特定に関寸る 研究成果も活用しつつ、天明・寛政期の客殿建築の一事例として明 らかにしたい。

2 大乗寺客殿について 大乗寺は行基によって天平 17 年（745） に開かれたとされている。衰退した時期もあったが天明年間の住職、 密蔵上人が再興を試み、弟子の密英上人が再興を果たしたと伝わっ
ている。大乗寺の境内には山門、観音堂 (本堂)、薬師堂、鐘楼、客殿、 土蔵がある。また、天明・寛政期には出石藩家老の仙石久賢が統治 していたことと関連して、仙石家から寄贈された額と仙石久賢の親 族の位牌が安置されている。

大乗寺客殿は桁行 16 間半、梁行 9 間半であり、入母屋造、銅板 莫注10) である（写真 1 ）。正面には唐破風の式台がとりつけられてい る。建物の下手側通りと大戸口に土台がある。床下をみると、礎石 建である。番付は一部だけであるが、いろは・漢数字の組合せ番付で、 柱の足元の背面側に書かれている。また、敷居は独鈷柄によって大 引に留められている。その上には大面取方柱を立て、身舎と縁側は 海老虹梁で繋いでいる。天井は仏間と上段の間が折上格天井、山水 の間は格天井であり、その他の部屋は棹縁天井である。畳は京間（6 尺 3 寸)、柱径を 6 寸と寸る助割である。大乗寺客殿の平面は、方丈 と土間と板間をもった庫裏を合わせたもので、方丈の中央に仏間が あり、その北側に上段の間がある。1 階に 12 室、2 階に 4 室の部屋 があり、円山応挙一門による障壁画がある部屋には障壁画の画意を 含んだ命名がされている注11)。

客殿の障壁画は、天明 7 年（1787）、天明 8 年（1788）、寛政 7 年（1795）の 3 度にわたって制作されていることが明らかになっ ている注 12)。現存する障壁画を観察したところ、山水の間障壁画の 一部が明治 37 年 (1904 年) 12 月 3 日から 18 日の間に盗難に遭い注 13)、修復されたことがある以外に切断痕は認められなかった。また、 

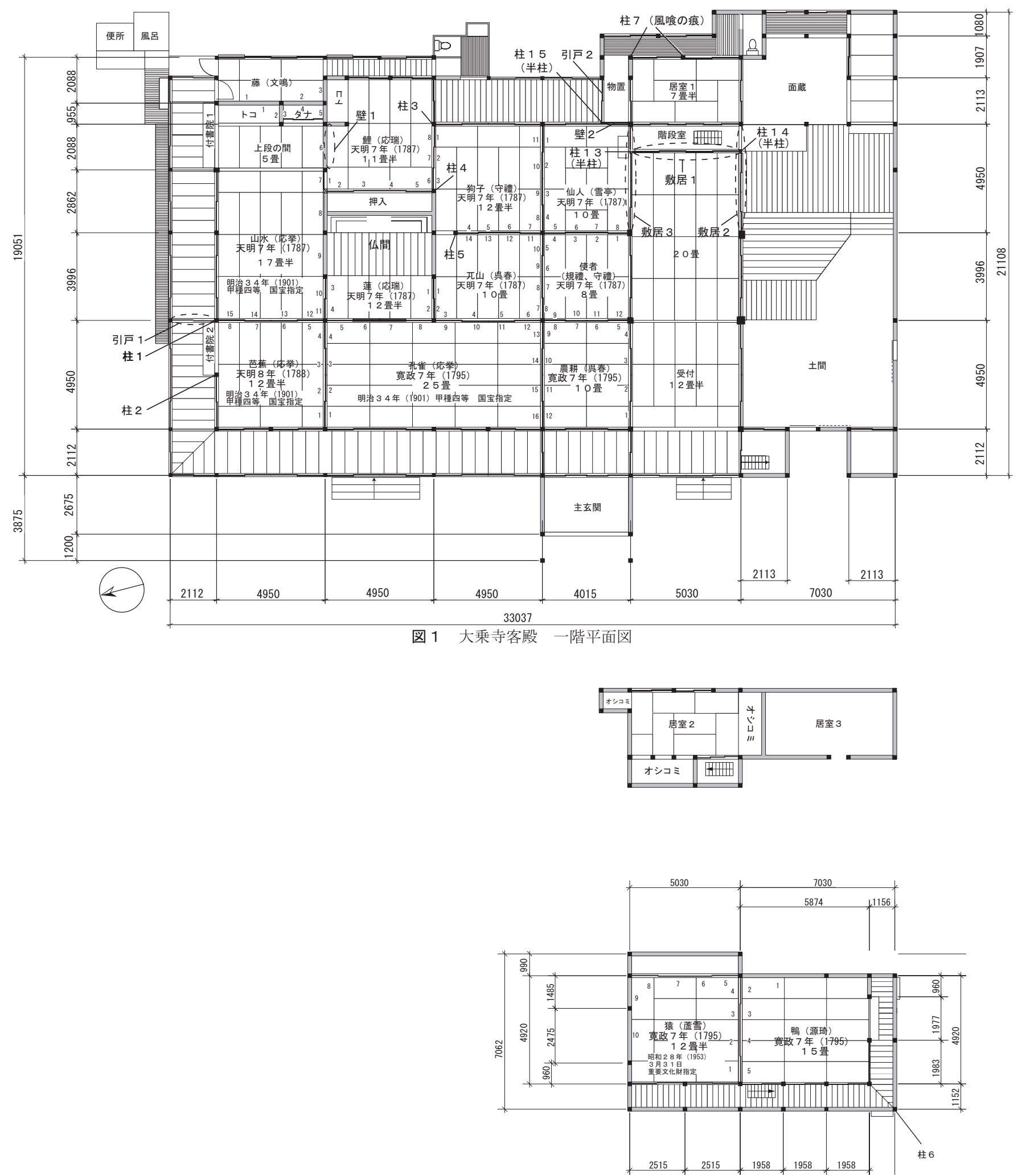

図 2 大乗寺客殿 二階平面図

図 1、図 2 の凡例について

各室の襖に付されている番号は、障壁画の番号であり、各部屋の障壁画ごとにカウントした。

図 1, 2の各室の中心にある文字の凡例は以下のようになる。

\section{部屋の通称（障壁画の作者名）}

製作年 和暦（西暦）

部屋の畳数
国宝保存法、古社寺保存法を

受けている障壁画は畳数の下に記した。 指定年 和暦 (西暦) 指定の種類 


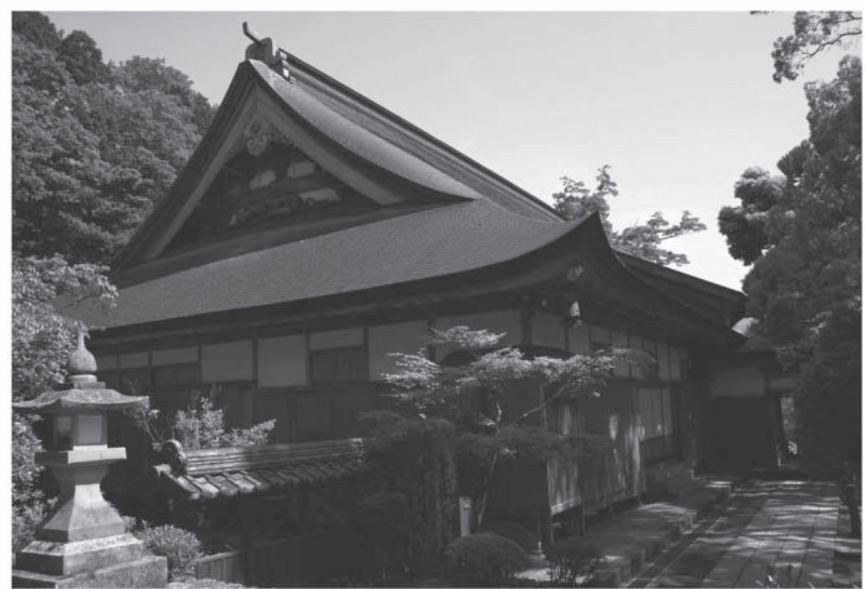

写真 1 大乗寺客殿全景 (北西側から撮影)

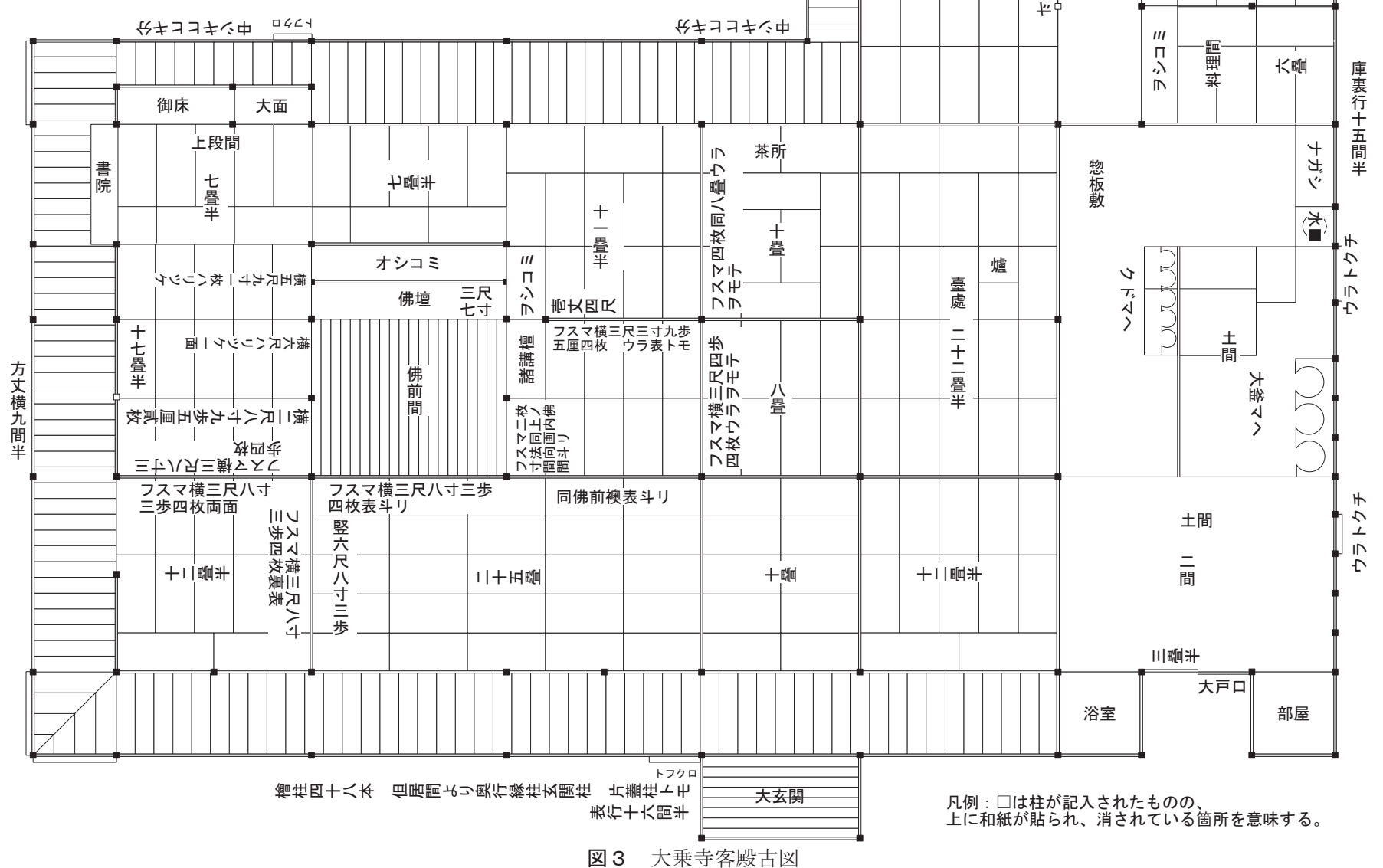

山水の間にある障壁画 7 は引戸であるが、障壁画 8 が前面にせり 出していために開閉できない状態であった。これを修䋨するため の工事が昭和 28 年 (1953) 3 月 30 日に行われている（図1)。

大乗寺は高野山真言宗の寺院として、弘法大師の命日に客殿の 元山の間に祭壇を設け、狗子、仙人、使者の間の襖を取り払い、 御影供を行っているほか、お盆に施餓鬼法要を営んでいる。また、 円山応挙一派による障壁画の一般公開を行っていたが、孔雀、芭蕉、 山水の間の障壁画は、平成 21 年（2009）4 月より隣接する収蔵庫 に移され、複製画を客殿内で展示している。

3 大乗寺資料の分析 大乗寺客殿に関する資料は、古図、置札、 昭和中期の住職であった長谷部环道上人注 14) による記録が現存して おり、これらを分析した。その際、必要に応じて既往研究を引用した。
また、分析のために客殿を実測し、平面図を作成した（図 1 、図 2 )。 3-1 大乗寺の再興と客殿再建の時期について まず、密蔵が天 明 6 年 (1786 年) 2 月 13 日に遷化し 注 ${ }^{15)} 、 5$ か月後の天明 6 年 (1786) 7 月に、密英が大乗寺を運営したいと願い出る証文がある注 ${ }^{16)}$

そこで、大乗寺客殿に関する置札が 2 枚現存している。いずれも 釷痕はなく、尖頭型の置札である。1 枚目は「再建沙門現住心城房 大阿遮梨密英敬白」とあり、密英が大乗寺客殿を再建するときに合 わせて作られた置札であることがいえる。年代として「寛政六歳甲 寅弥生十六日龜居山大乗寺」工事に関わった者として「大工棟梁後 見 豊岡彦四郎重賢」と書かれており、大乗寺客殿は寛政 6 年 (1794) 3 月 16 日に建築が開始されたことと、棟梁の後見が豊岡の彦四郎重 賢であることがわかる。この点について、『近畿地方の近畿社寺建築 5 』では寛政 7 年（1795）としており、誤っている。 
2 枚目の置札は年紀を欠くが、この工事に関わった人たちによる 「造営世話頭人」の札であり、豊岡彦四郎門人 森村大工 青山常吉」 をはじめ大工・杣人・鍛治・莫司ら 85 名の名前と、七ヶ村の造営世 話頭人 23 名の名前が記されているものである。この札より、但馬全 体から大工らが集まっていることがわかる。

1 枚目の置札には、「再建」と記されているが、これは客殿とされ た建築をもう一度建設することを指すのか、あるいは前述の証文の とおり、天明 6 年 (1786) 7 月から密英が大乗寺の再興に関わって きた一連の行為を指寸のかという問題が生じる。本稿では、決定的 な証拠を見出せないため、どちらか一方を指すのか、あるいは両方 を含蓄しているのかという 3 つの可能性を指摘するに留めたい。

3-2 古図 大乗寺には、3 枚の和紙を継ぎ足しし、墨で書かれ た図面が現存している。図面全体は $516 \times 560$ ミリで、さらに和紙を 裏打ちすることで補強されている。年紀と表題を欠くが、「庫裏十五 間半」「方丈横九間半」「庫裏横六間半」と記載されているように、 方丈と庫裏が一体となった客殿建築の平面図である。柱の素材、本数、 襖の大きさと枚数が記入されており、計画の具体性を認めることが できる。図 2 と比較し、大乗寺でこの図面と類似性が認められるの は客殿だけであり、客殿の計画図であると考えられる。また、置札 より寬政六年（1794）を遡って作成されたと考えられる。河野元昭 氏によれば、密英によって作図されたとしているが注 17)、柱の本数と 木材名が記入されている点から大工棟梁の手が加わっている可能性 も否定できない。これを本稿では「古図」と呼ぶことにし、採寸と 清書を行なった（図 3 )。次の 4 と 5 では、古図と現状および既往研 究を分析したときに見出された点を論述したい。

4 大乗寺客殿の方丈について ここでは、大乗寺客殿において調 查を行ったところ、発見が見られた式台、芭蕉の間、鯉の間、藤の間、 狗子の間について、順番に考察していくこととしたい。

4-1 式台について 農耕の間の手前にある玄関を、古図では「大 玄関」と記載されており、現在は「主玄関」と呼び、円山応挙の銅 像を設置しているが、これは式台と呼んでよいと考えられる。床下 調查を行ったところ、踏面と蹴込、力桁と側桁は鎹で留められ、角 釷が使われているので、工事時期は近代を遡ると考えられる。そし て、床板の側面には正面から向かって右から順番に「壱」「二」「三」 と墨書による番付が付されていた。式台の床下には平成 17 年 (2005) にジャッキアップの工事が行われ、部材が交換されたために当初の 状況を伺うことはできない。式台の欄間の裏側に「文政六年癸未年 新調」と中井権治正貞以下 5 名の彫物師の名前が裏側に墨書されて おり、文政 6 年 (1823) にこの欄間が新調されたと考えられる。

4-2 上段の間、芭蕉の間にある付書院に関して ここでは、上 段の間と芭蕉の間にある付書院について述べたい。古図では、芭蕉 の間に付書院がなく、上段の間に付書院が記載されているが、現状 では両方に付書院を確認できる。上段の間にある付書院 1 は、古図 では付書院となっているが、現在の付書院 1 は床の間との位置が異 なっており、取込み付書院となっている。この違いについて調査を 行ったところ、背面側の書院柱、台輪、地覆に変更の痕跡は見られ なかったため、客殿を建設する際に変更されたと考えられる。

芭蕉の間にある付書院 2 （写真 2 ）については、図 1 の柱 1 に長 押に釘隠が柱真からずれて打たれているが、元の柱真部に穴がなか
った。また、柱 2 は縁側の長押が、付書院 2 まで伸びており、釬隠 は柱真からずれて打たれている (写真 3 )。付書院 2 の縁側には引戸 1 があり、鴨居の上には土壁が屋根まで塗りこめられていた（図 1 、 写真 2 )。引戸 1 を調査すると付書院 2 の書院柱は引戸 1 の上框に合 わせた形状となっている（写真 4 ）。また、溝が背面寄りに彫られて おり、これは付書院 2 の存在を想定していると考えられる（写真 5 )。 この溝のうち、正面側の溝には戸の下框による引っ掻き傷がなく、 引戸 1 が開閉された痕跡が認められなかった。引戸 1 のうち、南側 の戸を開けると付書院 2 の小脇があるために通過できないので、引 戸1を開閉することはなかったと考えられる。

以上より、当初から付書院 1 と付書院 2 が存在していると考えら れる。大乗寺には出石藩家老の仙石家の位牌が安置されていること を 2 で述べたが、その出石藩と隣地にある豊岡藩注 18$)$ の政治的な折 衝の場として大乗寺客殿で面会が行ったという寺伝がある。しかし、 関連する文書を見出せず、 5-1 で述べる出石藩の公用執務日記『出 石藩御用部屋日記』においても、関連する記述を確認できなかった。 したがって、面会の実態は不明であり、付書院が 2 つ存在する理由 を明らかにすることはできない。

4-3 藤の間について 現在、上段の間の背面にある藤の間と呼 ばれている部屋は古図には記載されていない。現状の背面側の縁側 だった部分を藤の間とすることで、部屋が 1 つ増えている。ここは 慈照院客殿のように増築の事例がみられるため注 19$)$ 、増築の可能性が 推察された。そこで、調查を行うと、柱には痕跡が認められなかった。 次に、畳をはがして床板を観察すると、釷が打たれていた。これは、 畳を敷くことが想定されていたことを示すものであり、増築の根拠 を認めることができない。藤の間にある奥文鳴の障壁画は寛政 7 年 （1795）に制作されたのではないかと河野氏が指摘している注20。よ って、大乗寺客殿の建築が始まった後の制作と考えられるが、増築 の痕跡がなく、再建当初から藤の間は計画されていたと考えられる。 また、藤の間の北側に便所と浴室があるが、現住職によると、客殿 が建設された寛政 6 年（1794）当時を再現したとのことである注21)。

4-4 鯉の間について 現在、上段の間の南側に位置する鯉の間 について、古図と比較すると 2 点の相違点がある。1つめは古図に よれば、鯉の間は 7 畳半であり、背面側に縁側が取り付いているが、 現状では 1 室で 11 畳半となっており、右にある狗子の間と縁が連続 していない。2つめは、古図にはトコが記載されていないのに対し、 現状ではトコがある（写真 6 )。

現状をみると、東西の柱間寸法が畳割と一致しておらず、畳と敷 居のあいだに木材を差し込むことで修正している。よって、この部 屋はかつて東に向かってトコを含む鳁 5 枚分の拡張があったのでは ないかと想定された。そこで、鯉の間の畳をはがして床板を確認し たところ、トコの間をふくむ東側の畳には釷が打たれていたために 畳を敷くことを想定していたと考えられる。また、柱 3 には、長押、 鴨居、敷居などの痕跡を認めることはできなかった。さらに、天井 裏調査を行ったところ、柱 3 は梁が三方挿しになっており、取り替 えることができないことがわかる（写真 7 ）。

鯉の間の障壁画は図 1 のように 8 面が南から西をまわり、北に配 されている。鯉の間の障壁画は天明 7 年 (1787） 5 月 15 日に注文さ れ、同年 9 月 21 日に完成した。その際に描かれた襖の数が 8 面であり、 現在と合致していることが古文書により明らかになっている注22)。つ 


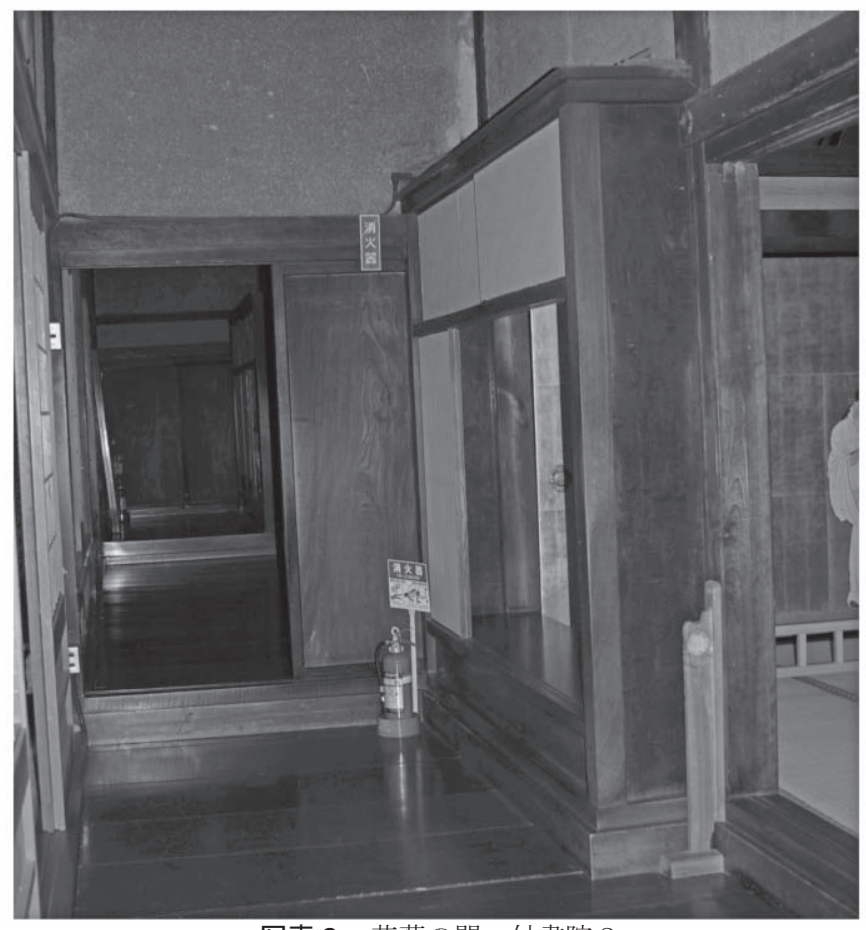

写真 2 芭蕉の間 付書院 2

(手前の柱が柱 2 、消火器の背後にあるのが引戸 1 である)

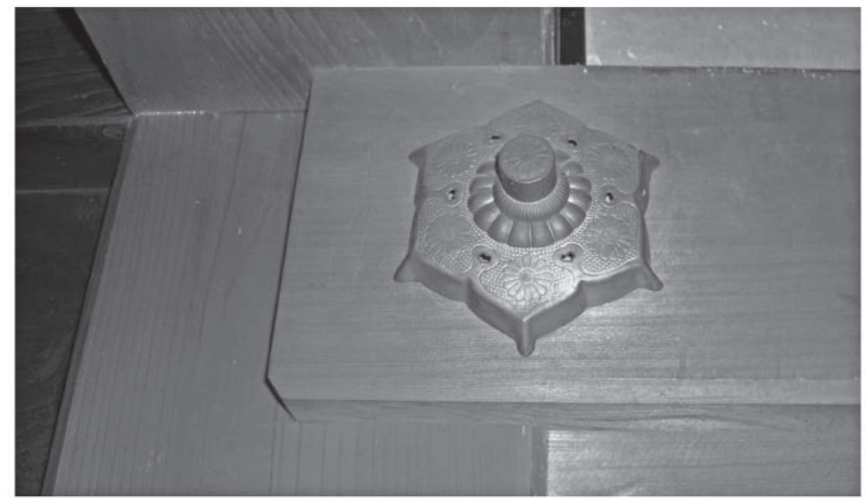

写真 3 付書院 2 にある柱 1 の上端部

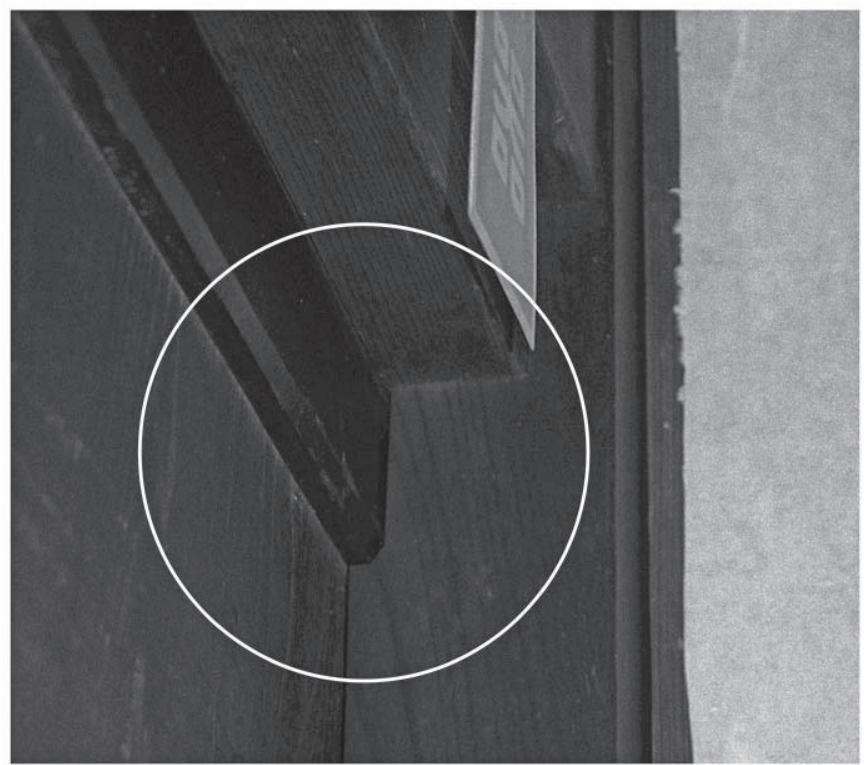

写真 4 芭蕉の間 付書院 2 の背面側にある書院柱と引戸 1 の上框

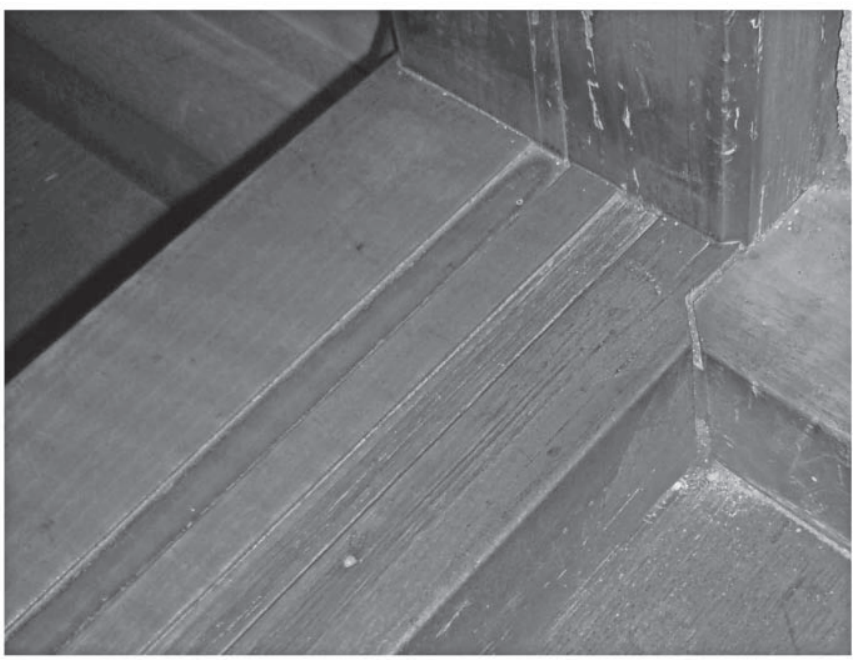

写真 5 付書院 2 の背面にある引戸 1 の敷居 (背面側から撮影した)

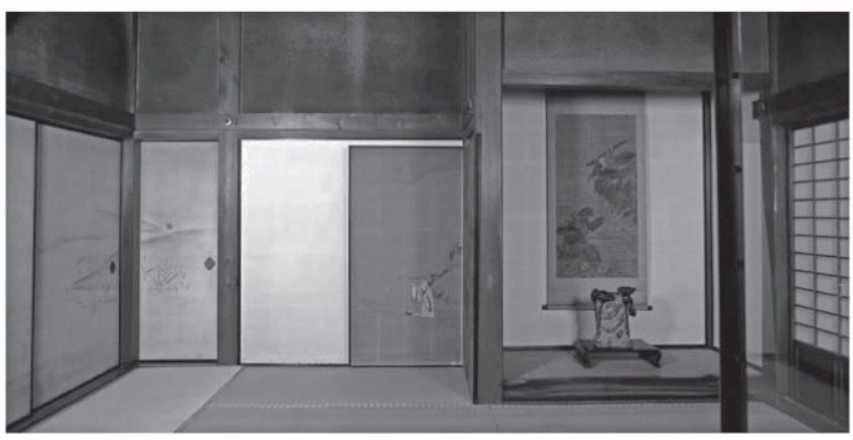

写真 6 鯉の間の北側 障壁画は右から 1，2 である。 (障壁画 1 を開けば、山水の間に出ることができる)

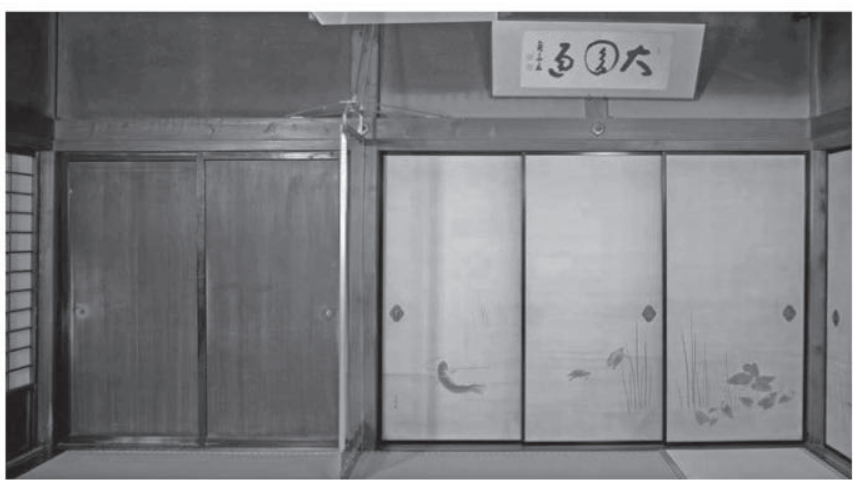

写真 7 鯉の間の南側 障壁画は右から 6,7,8 である。

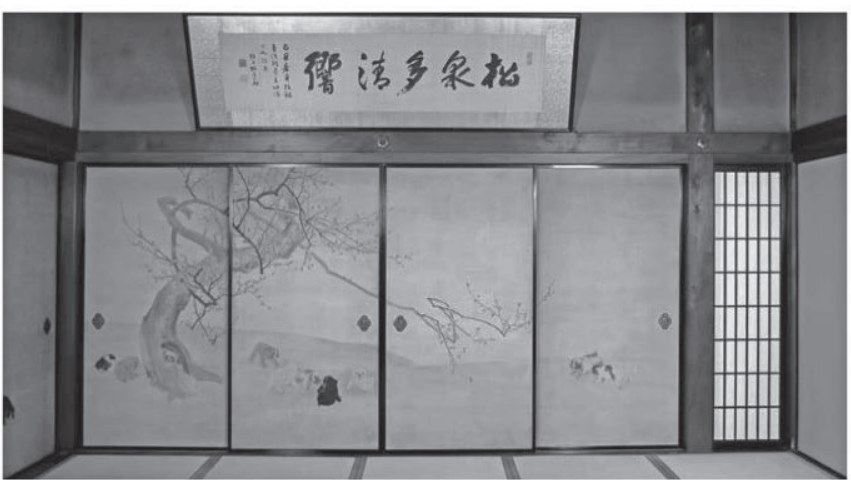

写真 8 狗子の間の西側 障壁画は右から 4, 5, 6, 7 である。 


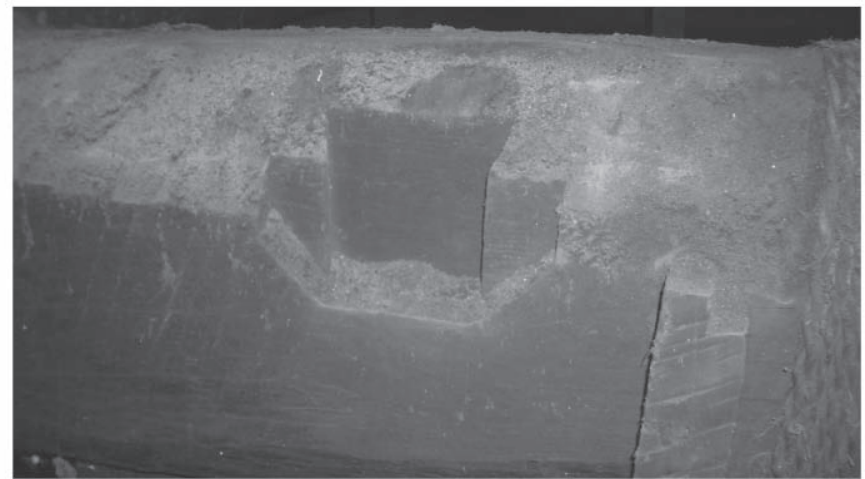

写真 9 庫裏の天井裏にあった仕口痕

まり、寛政 6 年 (1794) に客殿が建築される以前に、障壁画が完成 している。しかし、古図のとおりに建築されても壁 1 は白壁となり、 部屋全体を障壁画で埋めることはできない。

鯉の間にトコがある理由については、鯉の間の障壁画 1 が開閉可 能であり、山水の間に出られることから鯉の間は控えの間という意 味合いが与えられた室であると考えられる (写真 6 )。そのために背 面に拡張し、装飾の意味でトコが設けられたと考えられる。

4-5 狗子の間について 鯉の間の南に位置する狗子の間は古 図によると、「ヨシコミ」が北西部に記載されているが、現在は白 壁である (写真 8 の右端)。この「ヨシコミ」が取り払われたため に障壁画が不連続になったと河野氏が指摘している注23)。

そこで、柱 4 、柱 5 の調查と床調查を行ったところ、痕跡を確 認することはできなかったため、ヨシコミは建設される際から存 在していなかったと考えられる。柱 5 の床下には束がなく、構造 上の意味を成さない柱である（写真 8 ）。また、狗子の間の障壁画 については、天明 7 年（1787）9月 8 日付の画料受取証の存在が 明らかにされている注24)。つまり、鯉の間と同様に、客殿の建築 より先に障壁画が完成しているといえる。

4-6 兀山の間について 狗子の間の西に位置する兀山の間 は、古図では「諸講檀」と記入されている部分があるが、現状で は痕跡を確認することができない。これは弘法大師の命日に御影 供を行う際に設置される諸講檀であると考えられる。

兀山の間の障壁画については、天明 7 年 8 月 25 日付の画料受 取証があり、狗子の間とほぼ同時期に完成している注25)。諸講檀 の裏側に位置する北面の壁には障壁画がなく、白壁となっている。 これについて、先述の画料受取証をみると、「御婦すま拾四枚 群 山露頂之懸畫」と書かれている。これは 14 枚の山頂の障壁画が 描かれたことを示しており、現在も 14 枚の障壁画がある。よっ て、造営されたときは白壁に障壁画を設えていなかったといえる。 4-7 二階の猿の間、鴨の間について 大乗寺客殿の二階にある 猿の間、鴨の間と呼ばれる部屋は古図には記載されておらず、二階 への階段がある部屋は古図では「浴室」と記載されている（図2、 図 3 )。そこで、痕跡調查を行ったところ、階段室および 2 階に増築 の痕跡は認められなかった。縁側にある、外側の手すりは後補であ ったことが柱 6 の指物痕でわかるのみである（図 2 )。ところで、猿、 鴨の間はどちらも置札に書かれる寛政 6 年 (1794) より 1 年後の寛 政 7 年（1795）に製作されたと推定されている注26)。ここで、佐々木 丞平氏が根拠とする書簡には、猿と鴨の間について「當春八方々出 來之約二御座候所猶今出來不仕さて々々氣毒千萬奉存候思召侯段も」
とあり、完成が約束より遅れて申し訳ないと記述されている。このこ とから考察すると、寛政 6 年（1794）の時には、障壁画が未完成であり、 大乗寺が障壁画を待っていた状況であったと考えられる。

5 大乗寺客殿の庫裏について 大乗寺客殿の庫裏は土間、その東 の板間、面蔵、その北にある居室 1 、土間の北にある 20 畳と 12 冨半の部屋を指寸（図 1 )。ここでは、庫裏の突出部、居室 2 、居 室 1 とその周辺について、順番に考察していくこととしたい。

5-1 庫裏の突出部について 現在の居室 1 と面蔵の背面側は庭 になっているが、古図をみると突出部になっている（図 $1 、 2 、 3$ )。 そこで、前住職の長谷部环道上人が著した『大乗寺歴代記』注27) (以下、 『歴代記』）には「現今の竹の間面蔵を取り入れて更に東に六間に六 間の突出部あり其中に廿五疊平間七畳半上段、付の書院、羿一間を 始め葠蔵十二畳、啭寝蔵十畳 (内一坪仏間)、料理間、廊下、等あ り応挙筆、竹の間、全牡丹間、全雪の間、と呼びたるなり。此部 分東の山崩れの為倒壊、(現存の建物も梚口をかけて引直せし事口 碑として残れり）世し為裏側応急改造の侭現今に及べり、」と記述 されている。これは、「現在の居室 1 と面蔵より東側には 6 間と 6 間の突出部があり、そこには 25 疊の雪の間、 7 畳半の上段の間、 1 間の付書院、1 2 畳の寝蔵である牡丹の間、 10 畳の奥寝蔵であ る竹の間（うち 1 坪は仏間）、料理の間、廊下などで構成されていて、 竹、牡丹、雪の間は応挙筆である。この部分は東側の山崩れのため に倒壊してしまったため（現在の客殿も修繕をしていると口伝があ る)、応急修理を行い、現在に至っている。と読み取れる。

そこで、古図を確認すると、突出部にある各部屋の畳数と配置は 一致している注 28)。次に、天井裏調查を行ったところ、現在の庫裏 の天井裏に突出部に伸びる仕口痕を 2 箇所確認できた（写真 9 ）。 また、突出部にのびる桁も切断痕がみられた。これらの痕跡より、 庫裏の突出部は崩壊したと考えられる。その時期については、『歴 代記』の密英上人の条で「上人建立後五十年内外の出来事ならん と推定し得らる」と記述されており、「密英による建築である寬政 6 年（1794）から 50 年を経た天保 15 年あるいは弘化元年 (1844) を軸とした時期に倒壊したのではないか」と読み取れる。そこで、 柱 7 をみると外面に風喰が見られるため、長期間、外気に曝されて いた時期があることがわかる。現住職によると、柱 7 の背面にある 縁側は昭和期に増築されたとのことであった。また、居室 1 の足下 に番付は記入されていなかった。よって、柱 7 が風化しているのは、 庫裏の突出部が崩壊して時間が経過していることの傍証である。

崩壊した理由については、出石藩の公用執務日記である『御用部 屋日記』によれば、文政 13 年（1830）8 月 1 日に大乗寺のある美 含郡が大雨に見舞われ、山崩れが発生しているが、庫裏の突出部も 山崩れが原因で崩壊したから゙うかは関連文書を見出せなかった注 29 。

崩壊した突出部の部材を転用して豊岡市福田にある新宮寺本堂を 建てたと寺伝があるが、この建築は平成 12 年（2000）に再建され たために、建築調查を行うことはできない注30)。しかし、新宮寺に は文政期の寄進を示す墨書を確認できる釘隠が数点現存し、大乗寺 から移されたと伝わる襖の引手金具が遺されていた。これを大乗寺 の引手と比較すると、同一の意匠が認められた注31)。また、須弥壇 に「文政十二年六月 新宮四世幸前代新造営」の銘が、本堂の欄間 に「文政十三年十二月 伽藍造営」の銘が記されている。この欄間 
二枚には、本枠と欄間の意匠に大乗寺の芭蕉の間にある欄間と類似 性が認められる。まとめると、新宮寺の須弥壇が造営された文政 12 年（1829）6月、あるいは伽藍が造営された文政 13 年（1830）12月 を軸とする時期に大乗寺客殿の庫裏の突出部が崩壊し、残存した部 材を新宮寺の旧本堂に転用したといえる。崩壊の時期は、文政 13 年 （1830）8月の大雨による山崩れによる可能性が高いと考えられる。

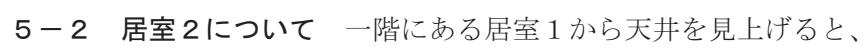
東西に二階梁が渡されているのが見え、二階の存在が想像されるが、 これが居室 2 である (図 2 )。居室 2 を調查すると、柱 $8 、 9$ は通し 柱であり、転用材ではないことがわかった。また、柱 $10 、 11$ 、 12 は間柱であった（図 4 )。次に、柱 8 と柱 9 は指物の痕を認め ることができ、柱 8 （写真１０）については展開図を作成した（図 5 )。柱 8 には膝の高さに指物の痕があり、A面から B 面にかけて天 井廻縁の痕、B面からC 面にかけて天井板のしゃくり溝の痕がある。 柱 9 （写真 11 ）には $\mathrm{E}$ 面に迴縁の痕、 D 面の上端に指物の痕（写 真 12 2) がある。柱 8 と柱 12 の間には敷居、鴨居と襖があるが、 鴨居の上にある内法貫には角釘が使われていた。最後に、柱 10 、 11 、1 2 には背面側の表面を板で打ち付けて補強されていた。板 の位置は何れも同じ高さであり、貫穴や小舞穴をふさいでいると考 えられる（図 4 )。以上より、居室 1 は大乗寺客殿が完成した当時は 突出部に伸び、居室 1 から柱 8 と柱 9 にある廻縁の痕跡までの高さ を備えた空間であったが、5-1で述べたように庫裏の突出部が崩壊 したあと、近代を遡る時期に居室 2 が作られたと考えられる。

5ー3 居室 1 について 現在の大乗寺客殿には居室 1 があり、か つて竹の障壁画があったために、寺は「竹の間」と呼んでいる。『歴 代記』には、「現今の竹の間面蔵を取り入れて更に東に六間に六間の 突出部あり其中に廿五疊」とあり、その後に「篓寝蔵十畳（内一坪 仏間)」と記されていて、一つの文章で竹の間の名前が二ヶ所見られ る。これは「現在の竹の間と面蔵より東側には 6 間と 6 間の突出部 があり、そこには 25 畳の雪の間と 10 畳の奥寝蔵である竹の間（う ち 1 坪は仏間) があった」と読み取れる。この点について分析したい。 まず、現状、古図、明治 25 年 11 月頃の座敷図を相互比較すると、 座敷図に居室 1 が認められ、明治 25 年 11 月頃にはすでに存在して

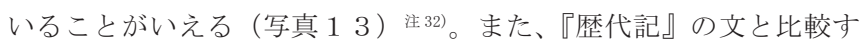
ると、居室 1 は「2 5 畳の雪の間」の一部であると考えられる（図 1 と 3 )。また、 110 畳の奥寝蔵である竹の間 (うち 1 坪は仏間)」は、 古図の「寝蔵奥部屋」と「内佛」の 2 部屋を指寸と考えられる (図 3 )。

竹の間の障壁画については、大乗寺客殿障壁画の写真集『大乘寺 靜觀』(光村写真部、明治 34 年 (1901)) によれば、竹の間障壁画と して襖 3 枚・3 枚・4 枚の 10 枚の写真が掲載されている。そして、 田島志一 (編)『真美大観』(第 14 巻、日本真美協会、明治 40 年 (1907)) にも、「寛政五年初秋の作に係る竹之間等の障壁画あり」と落款から 記述したと考えられる文がある。そして、浜田青陵は明治 41 年(1908) 10 月以前に大乗寺を訪問し、「竹の間 (八畳)」について「見るを得 ざりし」と存在を历めかしつつも見学できなかったことを記してい る注 33)。しかし、現在において竹の障壁画の行方は不明である注34)

『歴代記』を記した長谷部环道上人は明治 33 年頃には、大乗寺に おり注 35)、『大乘寺靜觀』『真美大観』『國華』において竹の間の障壁 画が紹介された時期を遡る。よって、『歴代記』で現在の居室 1 を 「竹の間」と呼んでいる記述は信をおいてよいと考えられる。しかし、

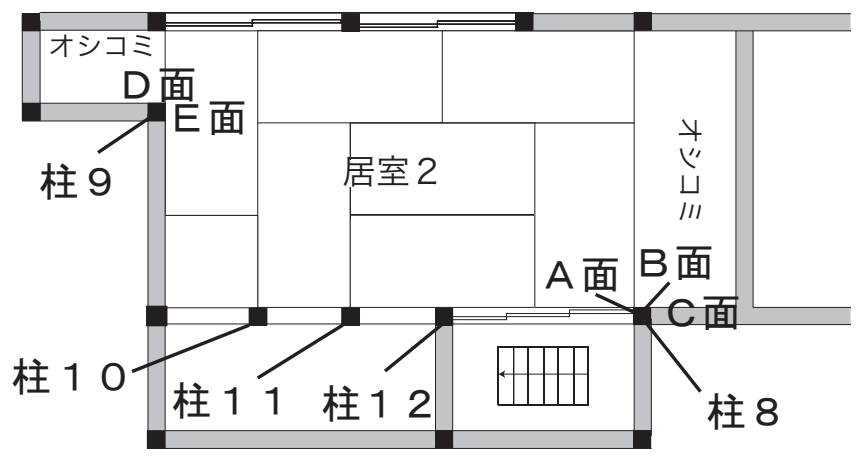

図 4 居室 2 の平面図

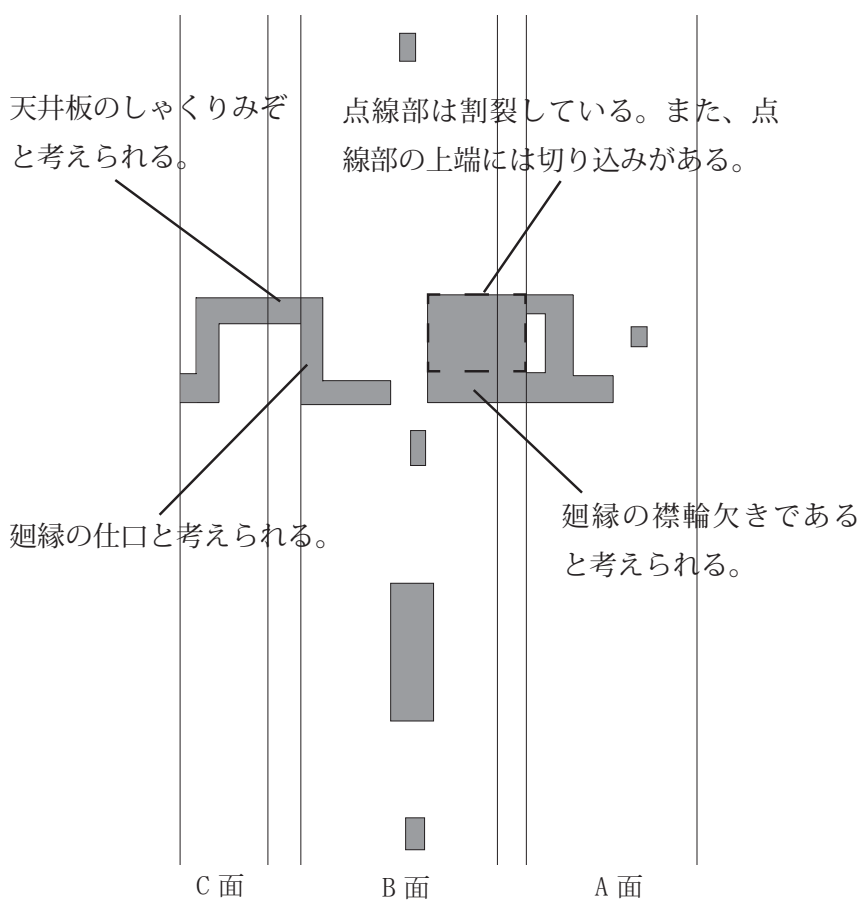

図 5 柱 8 の指物痕に関する展開図

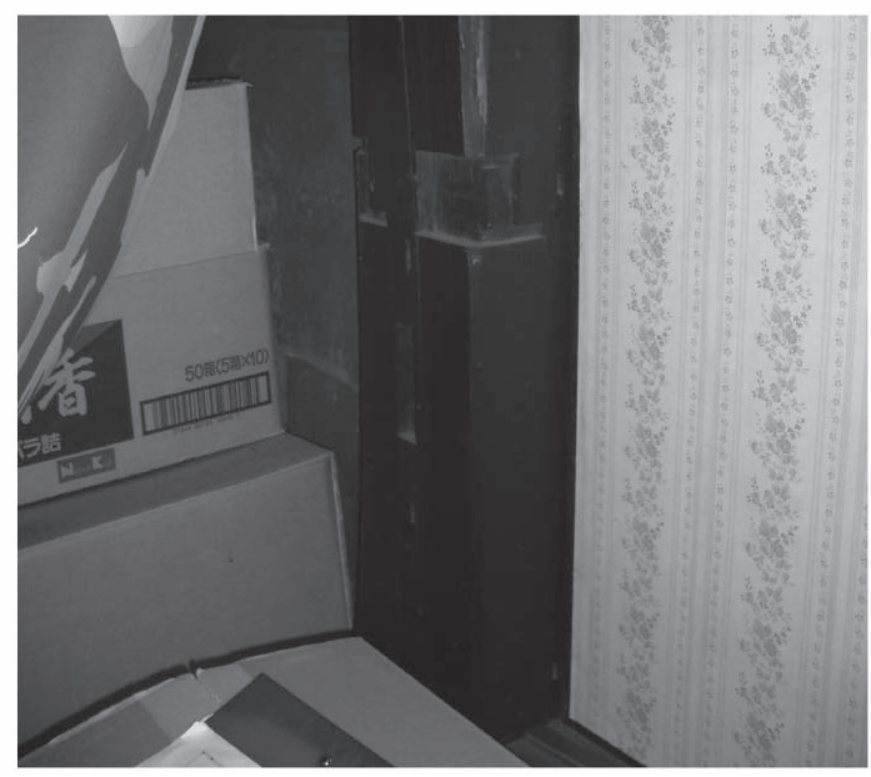

写真 10 居室 2 にある柱 8 の指物痕周辺写真 左面が B 面、右が A面である。 


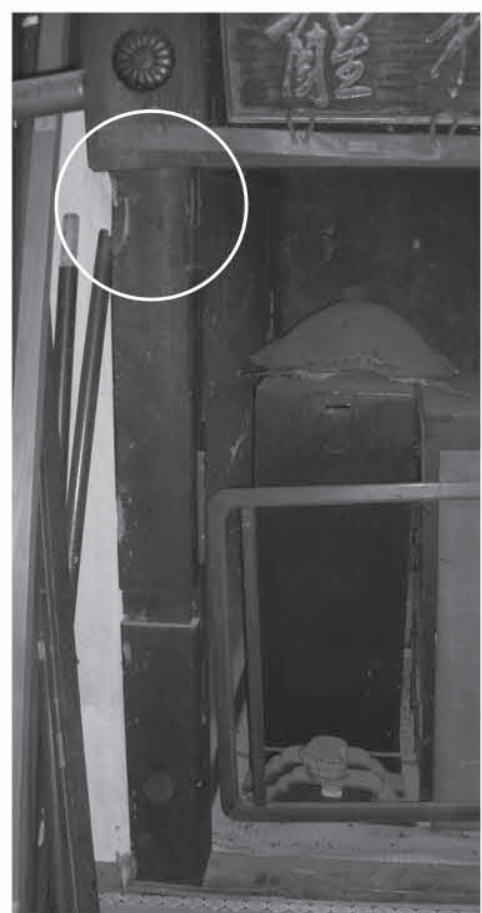

写真 11 居室 2 にある柱 9 の全体

手前が $\mathrm{E}$ 面、右側面が $\mathrm{D}$ 面である。

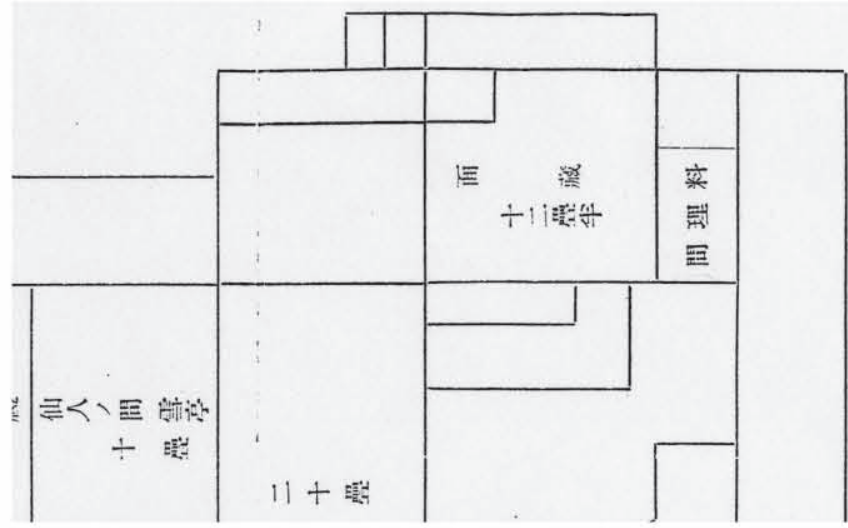

写真 13 「但馬城崎郡香住村大乗寺座敷圖」より居室 1 の周辺

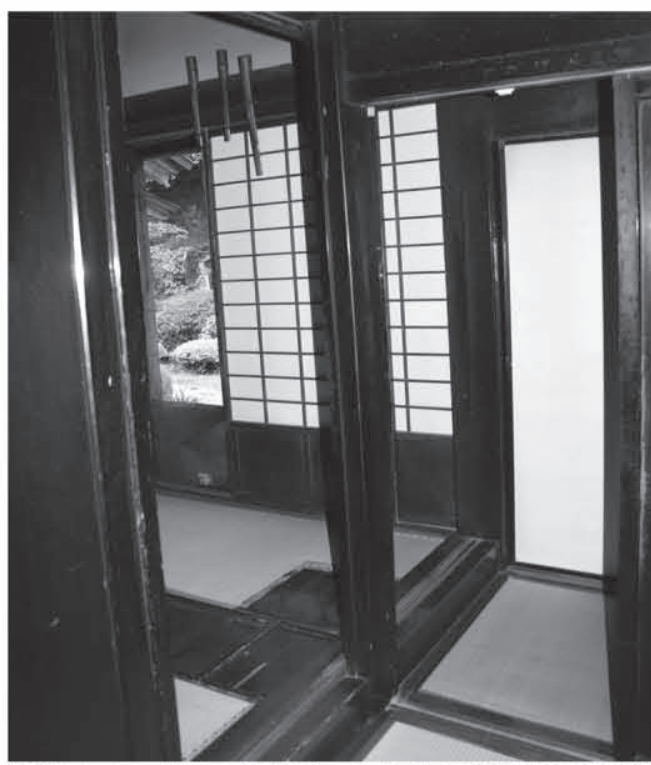

写真 14 柱 13 と敷居 1 と敷居 3 が接続する部分

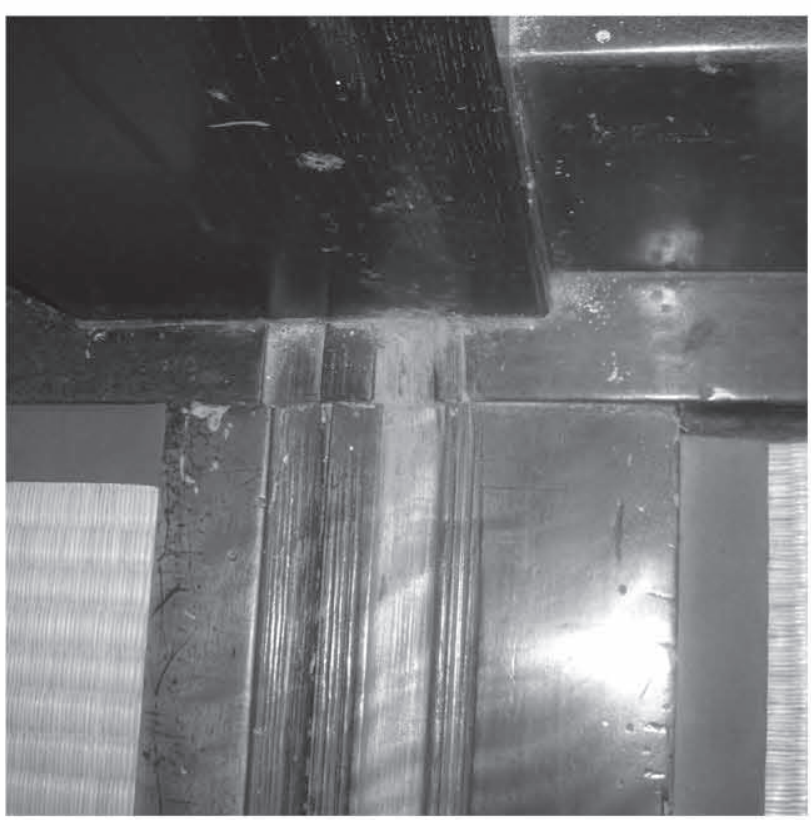

写真 15 敷居 1 と敷居 3 が接続する部分（拡大）

(手前にある敷居は、敷居 1 である)

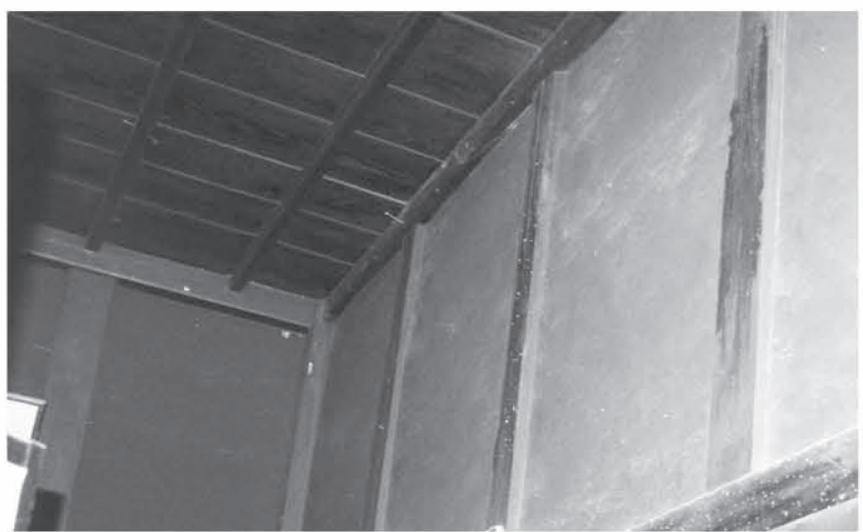

写真 16 敷居 1 の正面側から天井を撮影した写真

(北東を向いて撮影、右側の天井廻縁は敷居 1 の真上にある。)

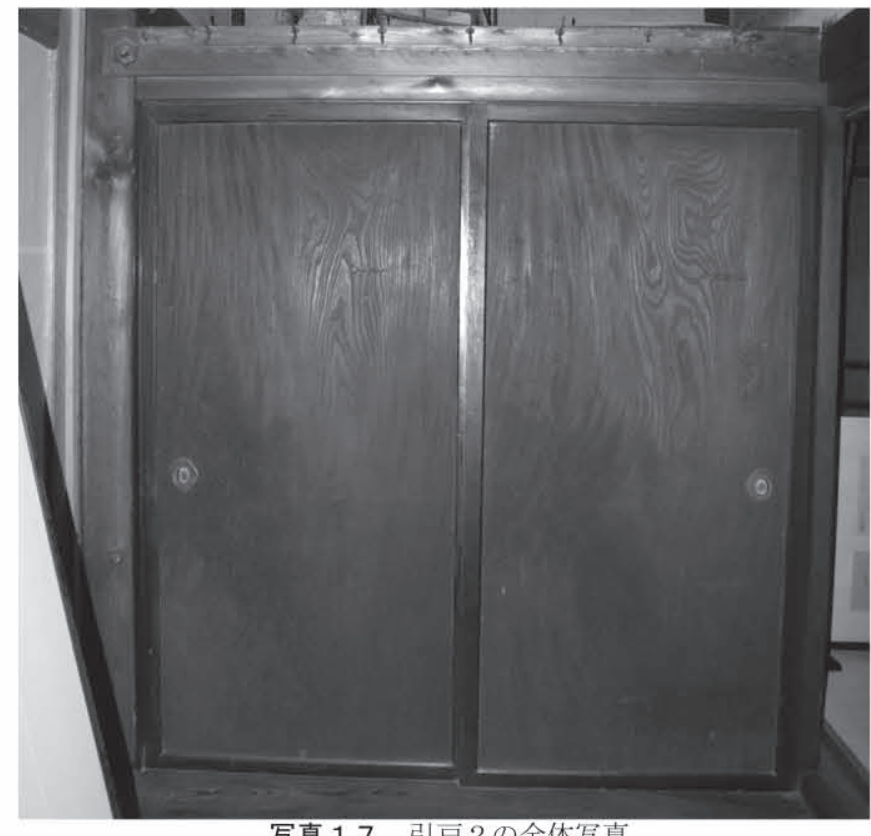

写真 17 引戸 2 の全体写真 


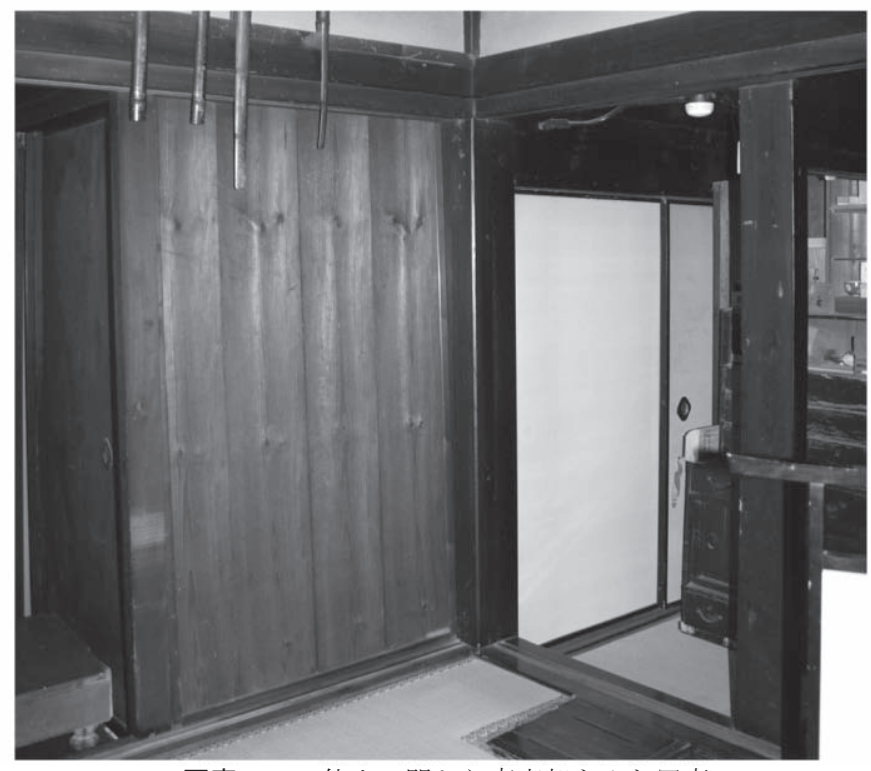

写真 18 仙人の間から南東部をみた写真

（左から引戸 2、柱 15 、壁 2 、右端の柱は柱 13 である。）

奥寝蔵を竹の間と呼んでいる根拠を見出すことができない。そこで、 密英筆の文書『応挙画軸物』では応挙筆の襖として「墨繪竹 常学 問處 六畳敷」と竹の障壁画が 6 畳の常学問處にあったと記され、 これは古図でいう 6 畳の面蔵であると指摘されている注36)。

ここでまとめると、客殿が建設された当初の居室 1 は 25 畳の雪 の間であり、竹の間の障壁画は古図でいう「面蔵」にあったと考え られる。庫裏の突出部が失われても、障壁画は明治 40 年までは大乗 寺にあった。その障壁画は面蔵から居室 1 に移され、保管あるいは 転用されたことがあったために、居室 1 が現在に至るまで「竹の間」 と呼ばれていると考えられる。

5-4 居室 1 の周辺について 居室 1 の正面側には階段室があり、 柱 13 は敷居 3 の上に、柱 14 は敷居 1 の上に立てられているが、 何れも半柱である。次に、敷居 2 と敷居 3 は襖を通すことができる (図 1 、写真 14 )。そして、敷居 1 は敷居 3 と柱 13 に接している が、襖を柱 13 に接することができるよう、溝を敷居 3 に彫ってい る（写真 15 )。また、階段室の西側にある 20 畳の部屋は棹縁天井 であり、棹縁が南北の方向にとめられている(写真 16 )。敷居 1 の 真上にある廻縁に最も近い棹縁を観察すると、他の棹縁と等間隔で はなく、廻縁に近い位置にある。また、敷居 1 の真上にある廻縁は、 丸みを帯びており、敷居 $2 、 3$ の真上にある角張った迴縁と意匠を 異にしている（写真 16 )。

また、仙人の間の背面側にある縁には引戸 2 と柱 15 があり、物 置となっている（写真 17 )。引戸 2 には敷居がなく、床板に溝を直 接彫っている。物置を構成している壁 2 は板壁であり、角釷で留め られている。以上より、この物置は近代を逆る時期の後補であると 考えられる（写真 18 )。最後に、居室 2 の南側には居室 3 があるが (図 2 )、部屋全体に壁紙が貼られており、痕跡を確認できなかった。

以上より、5-1と 5-3 で述べたように、庫裏の突出部が崩壊し た後に居室 1 が残ったと考えられるが、その周辺をみると、敷居 1 、 柱 13 、柱 14 が設置され、階段室が構成されたと考えられる。また、 物置を設置するために引戸 2 、柱 15 、壁 2 が取り付けられたとい える。つまり、居室 1 の周辺は古図と同様に建てられたと考えられる。
6 まとめ 大乗寺客殿について、現地調查と文書調查および既往 研究を総合的に分析した結果、以下のことがいえる。

1 、大乗寺は天明 6 年（1786） 7 月に密英による運営が始まり、大 乗寺客殿は寛政 6 年（1794）3 月 16 日に豊岡の彦四郎を後見とす る但馬地方の大工らによって建築が開始された。

2、障壁画の注文・製作がされたのは天明 7 年（1787） 8 月から寛 政 7 年 (1795) までの 8 年間である。このうち、藤、猿、鴨、孔雀 の間以外の障壁画は天明期に描かれている。このことから、図 3 の 古図は天明 7 年 8 月以前に製作されたと考えられる。

3、大乗寺客殿の芭蕉の間にある付書院、藤の間、鯉の間、狗子の 間、猿の間、鴨の間は後補ではなく、建築当初からである。

4、建築当時の庫裏の突出部は古図と同様であったと考えられるが、 新宮寺旧本堂が造営される文政 12 年（1829）6月と文政 13（1830） 年 12 月を軸とする時期に山崩れのために崩壊した可能性がある。 5 、居室 2 の柱 $8 、 9 、 10 、 11 、 12$ の指物痕より、庫裏の突 出部が崩壊した後に居室 2 が作られたと考えられる。

6、居室 1 が「竹の間」と呼ばれている理由は、明治 41 年 (1907) 10 月まで大乗寺にあったと思われる竹の間の障壁画が保管あるい は転用されたためだと考えられる。

7、敷居 1 、柱 13 、柱 14 、居室 1 の正面側にある階段室、物置 の引戸 2 、柱 15 、壁 2 は近代を遡る時期の後補である。

\section{謝辞}

本研究は大乗寺の長谷部眞道住職、山岨眞應副住職、新宮寺の川 端孝典御住職、香美町教育委員会の石松崇氏、味田晃氏、京都国立 博物館学芸部企画室長の久保智康氏、和歌山県文化財センターの鳴 海祥博氏、三井記念美術館の樋口一貴氏、横浜国立大学大学院都市 イノベーション学府建築都市文化コースの大野敏准教授よりご協 力・ご助言を頂きました。また、『出石藩御用日記』の読解には三 好英樹氏（当時、京都府立大学大学院生）に、現地調査には安田徹 也氏（当時、横浜国立大学大学院工学府社会空間システム学（建築）

大学院生）にご尽力を頂きました。皆様に深謝申し上げます。本 研究は平成 20 年度笹川科学研究助成（人文系）を受けました。

注

注 1）円山応挙（享保 18 年〜宽政 7 年（1733-1795)）江戸中期の画家。円山 応挙の表記は旧表記の「圓山應舉」を採用する文献もあるが、ここではデー タベースで検索する際の利便性から「円山応挙」とした。

注 2）大乗寺障壁画全体は昭和 44 年（1969）6月 20 日に国重要文化財指定を 受けている。

注 3) 密蔵（みつぞう＼cjkstart享保元年〜天明 6 年 $(1716 \sim 1786))$

江戸中期の大乗寺住職である。

注 4）密英（みつえい 宝暦 3 年〜享和 2 年 $(1753 \sim 1802) ）$ 江戸中期の 大乗寺住職であり、密蔵のあとを継いだ大乗寺住職である。

注 5）倉橋但斉『絵画円山派概説 大乗寺案内記』非売品，昭和 40 年（1965） 味田晃, 長谷部眞道『応挙・尅春・芦雪障壁画』兵庫県文化協会, 昭和 58 年 (1983)

味田晃「大乗寺と円山応挙」但馬史研究, 10 号, 但馬史研究会, 昭和 61 年 (1986)

味田晃「亀居山大乗寺と円山応挙私考」歴史手帖 兵庫県の歴史, 32 号 , pp. $29 \sim 38$, 平成 8 年（1996） 2 月

木下長宏「<失われた時〉を見出すとき（三十三）」あまだむ，平成 13 年 （2001）3 月号, pp. $4 \sim 6$, 平成 13 年（2001）

木下長宏「く応挙寺 [大乗寺] と美の運命〉を討議するシンポジウムを開い たことについて」月刊あいだ, 88 号, pp. 2 ～10, 平成 15 年（2003）4月 佐々木丞平・佐々木正子『至宝 大乗寺一円山応挙とその一門』国書刊行会, 
平成 15 年 $(2003)$

木下長宏「「美」をみることとは--大乘寺の襖絵を例にして」Diatxt,

京都芸術センター, pp $10 \sim 19$, 平成 15 年 (2003) 11 月

木下長宏「く失われた時>を見出すとき（五十二）」あまだむ，平成 16 年 (2004) 5 月号, pp. $2 \sim 4$, 平成 16 年 (2004)

篠原聰「鑑賞教育再考 大乘寺の襖絵空間をめぐり」東海大学課程資格教育 センター論集, pp. $23 \sim 34$, Vol. 4, 平成 18 年 (2006)

注 6) 國華 一○○号、二二一号、九四五号、一二○五号、國華社

高崎富士彦「但馬の大乗寺」MUSEUM, 90 号, pp. $24 \sim 27$, 昭和 33 年 (1958) 橋本綾子「大乗寺 - 古寺巡礼」佛教藝術, 65 号, pp. $71 \sim 80$, 昭和 42 年 (1967) 佐々木丞平, 佐々木正子『円山応挙研究 研究篇 図録篇』中央公論美術出版, 平成 8 年 (1996)

注 7）根立研介「兵庫 - 大乗寺 木造薬師如来坐像一躯 木造四天王立像 四駆」京都美術史学, 1 号, pp. $167 \sim 202$, 平成 14 年（2002）1月

注 8)『近畿地方の近世社寺建築 5 』(近世社寺建築調查報告集成 13), 東洋書林, pp. 90, 昭和 $53 \sim 54$ 年 $(1978-1979)$

多淵, 中西「兵庫県の近世社寺建築について 5 ・摂津・但馬・丹波の寺院建 築」日本建築学会学術講演梗概集計画系, pp. 2003-2004, 昭和 55 年 (1980) 注 9）大草一憲その他 2 名「近世臨済宗塔頭方丈と曹洞宗本堂について：邸 宅風本堂の系譜と特質について」日本建築学会近畿支部研究報告集, 計画系, 40 号, pp. $833 \sim 836,2000$ 年

注 10）屋根は昭和 12 年（1937）に瓦莫となり、唐破風は柿莫であったことが 地元民の小幡勝治郎氏が撮影した写真 (香美町教育委員会蔵) で確認できる。 注 11）部屋の名称については注 12 と図 1 、図 2 を参照されたい。

また、大乗寺は公式ウェブサイト「大乗寺円山派デジタルミュージアム」に おいて客殿内部のデジタルデータを公開しているので併せて参照されたい。

注 12）大乗寺には以下の部屋ごとに円山応挙とその一門による画が収蔵され ている。以下、概略と注文された年を示したい。括弧は担当した絵師名で ある。なお、年代については以下の文献を参照している。

河野その他「特輯 大乘寺の繪畫」國華, 九四五号, 昭和 47 年 (1972)

一階：農耕（呉春）寛政 7 年 (1795)

使者（規禮、守禮） 天明 7 年 (1787)

兀山（呉春） 天明 7 年 (1787)

佛間 (應瑞) 天明 7 年 $(1787)$

山水（応挙） 天明 7 年（1787） 12 月 明治 34 年 (1901)

甲種四等 国宝指 定

芭蕉（応挙） 天明 8 年（1788）1月（佐々木丞平，佐々木正子『円山 応 挙研究 研究篇 図録篇』中央公論美術出版, 平成 8 年 (1996), pp168) 明治三十四年（1901 年）甲種四等 国宝指定

孔雀（応挙）寛政 7 年 (1795) 明治 34 年（1901）甲種四等 国宝 指定 京都で起った天明の大火で焼失後、書き直されたことが佐々木氏に よって指摘されている。

藤（文鳴）河島元昭氏によって寛政 7 年（1795）に制作されたの

ではないかと指摘されている(前掲 國華 九四五号)。

鯉 (應瑞) 天明 7 年 $(1787)$

狗子 (守禮) 天明 7 年 (1787)

仙人 (雪亭) 天明 7 年 $(1787)$

二階:猿（長澤蘆雪） 寛政 7 年（1795）（前掲 國華 九四五号による）

鴨（源琦）寛政 7 年（1795）（前掲 國華 九四五号による）

注 13) 『但馬新聞』明治 38 年 1 月 1 日から同年 3 月 22 日のあいだ、計五回 にわたって掲載された記事より

注 14）長谷部琭道（はせべ・たくどう＼cjkstart明治 21 年〜昭和 42 年（1888〜 1967)）昭和初期から中期にかけて大乗寺住職であった。

注 15）大乗寺所蔵『歴代先師過去帳』（昭和三十九年九月二十八日作成）より 注 16）佐々木丞平「圓山應擧と大乘寺 新出文書を手がかりとして」國華, 一二○五号, pp $3 \sim 18$, 平成 8 年 (1996) 佐々木氏は天明 6 年 7 月の証文 に「美含郡森村大乗寺無住二付」とあることから、大乗寺は無住であり、建 築は荒れて果てていただろうと指摘した。さらに、香住の七日市天満宮には 再興に関する棟札があり、日付が「天明五年乙巳十月廿二日」で、「開眼供 養導師別当大乗寺仏子密英心城房」とあり、密蔵が遷化する天明 6 年 2 月 より前に密英が大乗寺に関係していた。よって、証文にある「無住」は単に 住職が不在であることを指し、期間は 5 か月であったと考えられるため、天 明 6 年の時点で、大乗寺が無住のために荒れ果てていたとは考えにくい。ま た、翌年の天明 7 年 5 月 15 日、密英は円山応挙に障壁画の制作を依頼する。 注 17）河野元昭「大乗寺円山派關係文書（特輯 大乘寺の繪畫）」國華,

九四五号, pp. $74 \sim 80$, 昭和 47 年 (1972)

注 18）但馬国城崎郡豊岡（現・兵庫県豊岡市）に置かれた外様大名京極氏の藩。
寛文 8 年 (1668) に丹後 (京都府) 田辺より京極高盛が 3 万 3000 石余で入 封している。城崎郡で 1 万石、美方郡が飛地で 5000 石余となった。

注 19) アンタリクサ，日向進「近世後期における京都の臨済宗寺院の本堂( 客殿, 方丈) に関する研究 平面の復原を中心に」京都工芸繊維大学工芸 学部研究報告 人文, 43 号, pp. $121 \sim 140,1994$ 年

注 20) 河野元昭「大乘寺と圓山派作家 (大乘寺と圓山派作家)」國華, 九四五号, pp. $3 \sim 11$, 昭和 47 年 $(1972)$

注 21）大乗寺の長谷部眞道御住職からの聞き取りによる。

注 22) 注 20 河野論文, pp. 7

注 23) 注 20 河野論文, pp. 8

注 24）注 20 河野論文, pp. 8

注 25）注 20 河野論文, pp. 9

注 26) 注 20 河野論文, pp. 10

注 27）墨で書かれている折本で大乗寺所蔵である。年代の表記に皇紀を使用 しており、昭和 20 年（1945）以前と考えられる。筆者は当時の大乗寺御住 職であった長谷部环道上人である。行基から前住職の長谷部隆諦上人（昭 和 3 年没）までの可能な限り、歴代住職とその業績を古文書や口碑を元に まとめている。古い事跡については史料に基づいて記されている。

注 28）『歴代記』では雪、牡丹、竹の間に畳数と部屋の名前を記入しているが、 この根拠となる史料を見出せない。國華の九四五号においても未検討である。 注 29) 出石町総務課町史編集室編『出石藩御用部屋日記 (CD-ROM 版)』出石町, 平成 16 年（2004） によると、文政 13 年 8 月 3 日の条に、一昨日の 1 日に 出石郡、養父郡、気多郡、美含郡で大雨があり、被害が出たことが伝えられる。 また、10月 15 日の条には「山抜崖崩 五千四百八拾四ケ所」堂社潰 三ケ所」 と広範囲の被害が報告されるが、大乗寺の名前を確認できなかった。

注 30）新宮寺には、本堂で使われていた松の床板が保管されていた。いずれ も面取りがされ、角釷が打たれている板もあった。既に新宮寺の旧本堂は解 体されている関係で当時の状況が把握できないのと墨書が確認できなかった ため、大乗寺との関係を示すことはできない。

注 31）新宮寺本堂の襖の引き手と釗隠が同寺に現存している。引き手が嵌め られていた襖は焼却してしまったが、もともと須弥壇の両脇にある室にはめ られていた襖で、向かって右側が竹に人物画で、左が鴨図の襖であったとい う。しかしながら左の鴨図はサイズが新宮寺本堂の敷居・鴨居の長さと合わ ず、襖の化粧縁の外側に木を嵌めて使用していたという。襖の引き手と釘隠 については、京都国立博物館学芸部企画室長の久保智康氏（金工工芸史）と ともに検討したところ、引手の魚々子や葉の形の意匠から、大乗寺と新宮寺 で使われているものは共通していると考えられるという結論が得られた。

注 32 ) 明治 25 年 11 月の日付があるパンフレット『亀居山大乗寺略記』(大 乗寺蔵）は裏に「但馬城崎郡香住村大乗寺座敷圖」があり、この一部を 写真 13 に掲載した。面蔵と仙人の間は現在と位置を変えていないため、 面蔵の北側にある部屋は現在の居室 1 であると考えられる。

注 33）浜田青陵「雑録」國華，二二一号、pp96 103 頁、明治四十一年十月 考古学者の浜田耕作（明治 14 年〜昭和 13 年 (1881-1938)）は竹の間を「八 畳」と規模を記しているが、注 32 の「座敷圖」で符合する部屋を確認する と居室 1 を指していると考えられる(ただし、居室 1 は 7 畳半である)。また、 階段室が記載されていないが、正面側に「二十畳」とあり、現状と一致して いることと居室 2 の調査結果より、階段室は略されているものと考えられる。 注 34）竹の間障壁画の行方については、三井南家九代目当主の三井高徳（明 治 7 年〜昭和 12 年 $(1874 \sim 1937))$ が大乗寺から譲り受けたと寺伝がある。 三井文庫『三井家文化人名録』151〜 152 頁, 2002 年によれば、「高徳は応 挙の正伝をつくる決意をし、応挙と門人たちの資料を集めるため、但馬や大 津に人を派遣して古記録、古文書を渉写し(後略)」とあり、応挙に関心を 深く寄せ、但馬に人を派遣している。よって、大乗寺を知っていたと考えら れる。この逸話は、倉橋但斉『絵画円山派概説 大乗寺案内記』(111 頁) で も確認できる。そこで、三井文庫の美術品を調査・展覧している三井記念美 術館の学芸員・樋口一貴氏のご協力のもと、調査を行ったところ、三井記念 美術館は三井南家の収蔵品を全点所蔵しているわけではなく、竹の間障壁画 の所在を明らかにできなかった。しかし三井高徳は独学で絵を学び、円山応 挙の画風を慕って写生主義に傾倒しており、明治 36 年（1903）には一夜一 枚応挙の粉本を写し、合計千数百枚に達したと樋口氏からご示唆いただいた。 注 35）注 13 の『但馬新聞』明治 38 年 2 月 8 日の記事によれば、「留守番僧玩堂」 が山水の間障壁画盗難事件の第一発見者である。そこで、長谷部玩道上人の 墓碑には「実應上人弟子入寺十二歳」と刻まれており、これは明治・大正期 の大乗寺住職・長谷部實應（弘化 2 年〜大正 10 年 (1845-1921)）の弟子に なったことを示す。注 14 より明治 21 年が生年であるので、明治 33 年頃に 大乗寺に入ったと考えられる。よって、「㻟堂」と同一人物と考えられる。 注 36$)$ 注 17 河野論文, pp. $79 \sim 80$ 